\title{
FANTOLY ZSANETT
}

\section{Rendészet és büntetőeljárás \\ az emberi jogok, az alapjogok, és az alkotmányos jogok viszonyrendszerében ${ }^{1}$}

A nemzetközileg elismert emberi jogok ${ }^{2}$ az egyéneket és azok közösségeit megillető egyetemes jogi garanciák: az államok azon beavatkozásai ellen jelentenek védelmet, amelyek az alapvető szabadságjogokat vagy az emberi méltóságot támadják, illetve a jogegyenlőséget sértik. Valójában az államok kezét kötik meg azáltal, hogy meghatározott cselekményekre feljogosítják, míg más magatartásformáktól eltiltják őket. Az emberi jogok nemzetközileg garantált, jogilag védett érdekek, amelyek mindig a humánum méltóságára fókuszálnak. Nem lehet róluk lemondani, minden embert egyaránt megilletnek. Az Emberi jogok egyetemes nyilatkozata mellett számos konvenció, deklaráció rendelkezik róluk, és biztosítja - csupán példálózó jelleggel - az élethez való jogot; a kínzó, kegyetlen, embertelen és megalázó bánásmód tilalmát; a tisztességes eljáráshoz való jogot; az önkényes szabadságelvonás tilalmát; a diszkrimináció tilalmát; a magánéletez való jogot stb. ${ }^{3}$

1 A tanulmány a KÖFOP-2.1.2-VEKOP-15-2016-00001 azonosítószámú, A jó kormányzást megalapozó közszolgálat-fejlesztés elnevezésű kiemelt projekt égisze alatt müködtetett Bünügyi Tudományok Kiemelt Kutatómühely 2016/244/NKE-RTK keretében, a Nemzeti Közszolgálati Egyetem felkérésére készült.

2 A cím értelmezéséhez megkerülhetetlen egy terminológiai probléma érintése. A nemzetközi egyezmények az emberek alapvető jogaira és szabadságaira az emberi jogok kifejezést használják, míg a magyar alkotmányjogban az alapjogok, állampolgári jogok, alapvető jogok (mint alkotmányos, tételes jogi fogalom), alkotmányos alapjogok kifejezésekkel találkozhatunk. Az Európai Közösségek jogában az alapjogok, alapvetö jogok kifejezést használták, míg általában az unió jogában az emberi jogokat. Mindezek alapján az emberi jogok-alapjogok elnevezésbeli kettősség fenntartható, attól függően, melyik jogterületről beszélünk. A két fogalom azonban lényegében ugyanazt jelenti, és ez kiderül az Európai Bíróság 2/94. számú véleményéből. 2/94 vélemény: „A Közösség csatlakozása az Emberi Jogok Európai Egyezményéhez" [1996] EBHT I-1759, különösen 33. és 35. pont. Az Európai Közösségeken belül az emberi jogok kifejezést nem tartalmi eltérés miatt, hanem azért kerülték el, és használták az alapjogok, alapvető jogok kifejezést, hogy szervezetekre is lehessen alkalmazni, ne csak természetes személyekre (Josephine Shaw: Law of the European Union. Palgrave, Basingstone. 2000, p. 331.) Blutman László: Az Európai Unió joga a gyakorlatban. HVG-ORAC, Budapest, 2014 http://www.tankonyvtar.hu/hu/tartalom/tamop425/2011_0001_548_EUjog/ch10.html

3 Az emberi jogok univerzális védelmi szintjét a Polgári és politikai jogok nemzetközi egyezségokmánya és az ENSZ Emberi Jogi Bizottsága garantálja; míg regionális szinten az Emberi jogok európai egyezménye, az Emberi Jogok Európai Bíróságának gyakorlata és az Európai Unió Alapjogi Chartája a meghatározó jogforrás. 
A jogállamiság, alkotmányosság kérdésköre az emberi jogokon mint kapcsolódási pontokon keresztül a jogágak közül legerősebben a büntető anyagi és -eljárási joghoz köthető, hiszen e jogterület avatkozik bele a legmélyebben az állampolgárok személyes szférájába. A legalapvetőbb emberi jogok, a humánus és tisztességes, tehát jogállami és alkotmányos büntetőeljárás, csak szigorú elvek és garanciák alapján kialakított eljárási kódex útján biztosíthatók. ${ }^{4}$

Nemzeti szinten a rendőrség az emberi jogok fontos védelmi vonala. A rendőr a jog - és így az emberi jogok - feltételen védelmezője. A rendőrség alapvető feladata a bủncselekmények megakadályozása és felderítése. A jogállamiság fokmérője lehet, hogy e - bünügyi rendészeti - feladatának teljesítése közben a rendőri hatalom milyen mértékben tartja tiszteletben az emberi jogokat. A hatékony bünüldözés a rendőrség jogvédő tevékenységének köszönhető; annak, hogy a büntetőjogi normák gyakorlati alkalmazása során a rendőrök figyelemmel vannak - egyebek között - a kínzás tilalmára; az önkényes őrizetbe vétel és letartóztatás tilalmára; a (rasszista) diszkrimináció elkerülésére; a jogellenes, önkényes eljárás megelőzésére stb.

A rendészeti szakirodalom a rendészetet negatív közigazgatásnak nevezi azért, mert feladata jogellenes emberi magatartásokból keletkező veszélyek legitim erőszak-monopólium birtokában történő elhárítása. ${ }^{5}$ A rendészeti in-

4 Székely György: Büntetőeljárási alapelvek mint a jogállamiság garanciái. Jog - Állam - Politika, 2009/3. 5 A fogalmi határok tisztázása érdekében előrebocsátandó, hogy hatályos joganyagainkban a rendészet és a rendvédelem sokszor szinonim fogalmakként szerepelnek, és esetenként keverednek is. A definiálás az elméleti jogászok feladata. Szamel Lajos szerint például a rendvédelem a közigazgatás azon ágazata, amely jogsértőnek minősített emberi magatartásoktól a hatósági kényszer eszközeivel védi a társadalmat (Szamel Lajos: Jogállamiság és rendészet. Rendészeti Szemle, 1992/3., 11. o.). A szerző a rendészetet is definiálta: olyan állami tevékenyég, amely a közrend megzavarásának megelőzésére, a közvetlenül zavaró magatartás megakadályozására és a megzavart rend helyreállítására irányul (Szamel Lajos: A rendészet és a rendőrség jogi szabályozásának elméleti alapjai. Magyar Tudományos Akadémia Államtudományi Kutatások Programirodája, Budapest, 1990, 30. o). Részünkröl Finszter rendészetfogalmát találjuk leginkább pontosnak. Szerinte a rendészet a modern államban az a közigazgatási tevékenység, amelynek társadalmi rendeltetése a jogellenes emberi magatartásokból keletkező veszélyek elhárítása [Finszter Géza: A rendészet átalakulásának húsz esztendeje (1988-2008). In: Sándor Péter - Stumpf Anna - Vass László (szerk.): Magyarország politikai évhuszadkönyve: A magyar demokrácia kormányzati rendszere (1988-2008). Demokrácia Kutatások Magyar Központja Közhasznú Alapítvány, 2009]. Mindkét fogalom (rendészet, rendvédelem) közös sajátossága, hogy állami tevékenységre utal, a szakigazgatás egy ágaként besorolandó, és célja a közrend fenntartása, valamint a megzavart közrend helyreállítása, esetenként legitim erőszak alkalmazásával. Az alkotmány 2004-es módosítása a rendvédelem kifejezést emelte normatív fogalom rangjára, bár a szakirodalomban ezt követően éles viták születtek a fogalmak tisztázása tárgyában. A közrend és a közbiztonság oltalmazása feladat kapcsán az Alkotmánybíróság vonatkozó határozatából következtetve számunkra itt csupán az a tétel releváns, hogy a közbiztonság általánosságban nem jelölhető meg valamely alapjog korlátozásának okaként. Ugyanakkor a terrorizmus elterjedése nem csupán a biztonsági felhatalmazásokat növelte, hanem a nemzetbiztonsági és bünüldözési feladatokat is közelítette egymáshoz. 
tézkedés eszköze lehet a törvényes erőszak, amely az alapvető emberi jogok jelentős korlátozásával járhat; a kényszerintézkedések sérthetik az emberi méltóságot is. Az egyik alapvető rendészeti feladat, a bünüldözés gyakorlása során tehát nem ritka, hogy sor kerül az emberi jogok, alapjogok korlátozására. Abból kell kiindulnunk, hogy az alapjogoknak csupán önkényes korlátozása tilos, illetve hogy az egyik alapjog korlátozása gyakran egy másik alapjog érvényre juttatásának eszközéül szolgál, ilyenkor a szükségesség és arányosság tesztje nyújt zsinórmértéket az önkényesség kizárásához. ${ }^{6} \mathrm{Az}$ alaptörvényben az alapjog-korlátozásnál rögzített szükségesség-arányosság tesztje mellett az alapjogi dogmatikában az alkalmasság tesztje is megkövetelt. ${ }^{7}$ Alaptörvényünk szerint „,... az ember sérthetetlen és elidegenithetetlen alapvetö jogait tiszteletben kell tartani. Védelmük az állam elsörendü kötelezettsége. Magyarország elismeri az ember alapvetö egyéni és közösségi jogait. Az alapvetö jogokra és kötelezettségekre vonatkozó szabályokat törvény állapítja meg. Alapvetö jog más alapvetö jog érvényesülése vagy valamely alkotmányos érték védelme érdekében, a feltétlenül szükséges mértékben, az elérni kivánt céllal arányosan korlátozható." A szükségesség, alkalmasság és arányosság tesztjét az Alkotmánybíróság az 1990-es évek elején dolgozta ki a német alkotmánybírósági ítélkezés hatására. A teszt alapján akkor alaptörvény-konform az alapjog-korlátozás, ha annak oka közvetlenül az alaptörvényre visszavezethető, továbbá az alkalmazott beavatkozás a cél elérésére alkalmas, és az ez alapján okozott alapjogsérelem mértéke az elérni kívánt céllal összhangban áll. ${ }^{9}$ Az eszköz és a módszer alkalmasságának követelménye az öncélú alkalmazás tilalmát, míg az arányosság a legenyhébb eszköz megválasztásának követelményét jelenti. ${ }^{10}$

A korlátozás lehetséges eseteit és azok feltételrendszerét törvényben kell meghatározni azzal, hogy a korlátozásnak vannak olyan eszközei és módszerei, amelyek alkalmazására még törvény sem adhat felhatalmazást. Ilyen pél-

\footnotetext{
6 Az Alkotmánybíróság álláspontja szerint a büntetőjogi szankcióval sok tekintetben hasonlóságot mutató és ahhoz szorosan kapcsolódó rendészeti jellegű intézkedéseknek is alkotmányos indokokon kell alapulniuk, szükségeseknek és arányosaknak kell lenniük. A jogállamiság lényegével összeegyeztethetetlen, hogy az alapjogi korlátozásokat is jelentő közbiztonsági intézkedés időtartama hosszabb legyen, mint ameddig az a célja szerint feltétlenül szükséges, és súlyosan sérti a jogbiztonságot, ha a szabályozás ellentmondásai vezetnek ilyen eredményre [47/2003. (X. 27.) AB határozat].

7 Balogh Zsolt - Hajas Barnabás - Schanda Balázs: Alapjogok és alapvető kötelezettségek fogalma, értelmezése. Nemzeti Közszolgálati Egyetem, Budapest, 2014, 7. o.

8 Szabadság és felelősség cím I. cikk.

9 2/1990. (II. 18.) AB határozat, ABH 1990, 18.

10 Révész Béla: Források a titkosszolgálatok politológiai tanulmányozásához. JATE Press, Szeged, 2012, 121. o.
} 
dául a kínzás és a megalázó bánásmód tilalma, a védelemhez való jog korlátozása és a nullum crimen/nulla poena sine lege elvének áttörése.

Az alapjog-korlátozás során alkalmazandó alapjogi teszt tehát olyan értékelési művelet, amelyet a jogalkotásnak és a jogalkalmazásnak is el kell végeznie. Arra ad választ, hogy indokolt-e valamely alapjog korlátozása. A korlátozás akkor indokolt, ha valamely más alapjog védelme érdekében szükséges. A jogalkotás során az is vizsgálandó kérdés, hogy valamely - hatóság által oltalmazott érdek - bír-e olyan társadalmi jelentőséggel, amely az egyes emberi jogok korlátozását indokolttá teszi, illetve hogy a jogkorlátozás arányos-e a védett társadalmi érdekkel. ${ }^{11}$

\section{Jogállami rendészet, jogállami büntetőeljárás}

A modern rendőrségnek meg kell küzdenie a szakmai elismerésért. Ennek egyik oka az volt, hogy egészen a XIX. század végéig hiányzott a rendészet jogi szabályozása. A közbiztonságot védelmezö közjog kialakulása azt eredményezte, hogy a betartására kilátásba helyezett kényszer alkalmazását ahogyan azt Max Weber írja - ,az emberek egy külön erre felkészült csoportjára"'l2 bízza. A jog azonban a különböző rendőrségi feladatokat eltérö részletességgel képes szabályozni. ${ }^{13}$

A ,,jogállam” kifejezést - németül - elöször Robert von Mohl jogászprofesszor, az 1848-as német nemzetgyülés tagja használta az állami szervek, elsősorban a rendőrség önkényének ellenálló jogrendre. ${ }^{14} \mathrm{~A}$ jogállam kifejezés tehát éppen az alapjogok és a rendészet konfliktusából, illetve azzal összefüggésben született meg. ${ }^{15}$

Mivel a büncselekmények a társadalom jogrendjét támadják, a büntetés joga az államot mint közhatalmat gyakorló jogi identitást illeti. A büntető igazságszolgáltatás állami monopóliumából a büntetőigény érvényesítésének kötele-

\footnotetext{
11 Finszter Géza: Bünüldözés és jogállam. Ügyészségi Szemle, 2016/1., 8. o.

12 Max Weber: Gazdaság és társadalom I. KJK, Budapest, 1987, 61. o.

13 Finszter Géza: A rendészet és a rendészeti igazgatás elmélete. Kézirat. 2018

14 Felkai Gábor: Búcsú a szociológiától. Jürgen Habermas új jogelmélete. Szociológiai Szemle, 1994/1., 168. o.

15 Robert von Mohl: Die deutsche Polizeiwissenschaft nach den Grundsätzen des Rechtsstaats. Tübingen, 1833. Ma a Polizeiwissenschaft elsődlegesen rendészettudományt jelent, abban az időben azonban tágabb értelemben, a közigazgatás és államtudományok körében használták. Ezzel együtt is meghatározó volt már akkor a rendészeti igazgatási vetülete. Koi Gyula: Külföldi hatások a magyar közigazgatás-tudományban. PhD-értekezés. Széchenyi István Egyetem Állam- és Jogtudományi Doktori Iskola, Győr, 2013, 40-45. o.
} 
zettsége következik. A büntetőigény késedelem nélküli érvényesítése az államnak a társadalommal szembeni alkotmányos kötelezettsége, a jogállamiság normatív tartalmából és a tisztességes eljáráshoz való alkotmányos alapjogból levezetett alkotmányos követelmény. ${ }^{16} \mathrm{~A}$ büntetöigény érvényesítésére vonatkozó állami kötelezettség ellátásához az állam büntető igazságszolgáltatásban közremüködő szerveinek hatékony eszközöket kell kapniuk. Az Alkotmánybíróság döntései ugyanakkor rámutatnak arra is, hogy a büntetőhatalom gyakorlásának intézmény-, illetve eszközrendszere közvetlenül alkotmányos jelentőségü, s a demokratikus jogállamban a bünüldözés is csak az alkotmány rendelkezéseivel összhangban álló, szigorú, az anyagi és az eljárási jogszabályok által meghatározott rendben folyhat. ${ }^{17}$ Ugyanakkor az államszervezet demokratikus müködése magában foglalja azt, hogy az állam, szerveinek tevékenységén keresztül eleget tesz az alapvető jogok tiszteletben tartására és védelmére vonatkozó alkotmányos kötelességének. Az államnak kötelessége az alanyi jogok védelme mellett az egyes szervek müködését úgy kiépíteni és fenntartani, hogy azok az alapjogokat - alanyi igénytől függetlenül is - biztosítsák. ${ }^{18}$

Mindannyian ismerjük az érvelést arról, hogy az emberi (terhelti) jogok erősítése egy idő után a joghatékonyság ellen hat, mivel ha minden elkövetőt minden büncselekmény miatt felelősségre akarunk vonni, akkor esetenként át kell törnünk a tisztességes eljárás mintaszabályát. Lehet-e jogszerü egy terrorista kényszervallatása, ha tudjuk, hogy megakadályozható az általa elrejtett bomba detonációja - és ezáltal tíz ember biztos halála - azzal az információval, amelyet a vallomásából megtudhatunk? Másként minősül az értékelés, ha ezzel nem tíz, hanem ezer vagy tízezer ember életét menthetjük meg?

Németországban 2004 decemberében a frankfurti bíróság tízezer-nyolcszáz euró pénzbírságra ítélte Wolfgang Daschner rendőrfönök-helyettest, aki vallomás kikényszerítése céljából kínzással fenyegette meg egy tizenegy éves kisfiú túszejtőjét. A tényállás szerint a sértettet, egy tehetős bankárcsalád fiát az iskolából hazafelé menet rabolta el a joghallgató elkövető, és a sértett szabadon bocsátását egymillió euró megfizetéséhez kötötte. A család megfizette a váltságdíjat, a rendőrség pedig nem sokkal később örizetbe vette az elkövetőt, aki élt a hallgatás jogával. Mivel a rendőrség elött ismeretlen volt, hogy a sértett élete megmenthető-e még, az események felgyorsítása céljából a nyomozást folytató rendőrfőnök kényszervallatásra adott utasítást kollégájának. Arra utasította beosztottját, hogy közölje a gyanúsítottal: ha nem tesz

16 42/2005. (XI. 14.) AB határozat, ABH 2005, 504., 517-518.

17 2/2007. (I. 24.) $\mathrm{AB}$ határozat, $\mathrm{ABH} 2007,65$.

18 36/1992. (VI. 10.) AB határozat, ABH 1992, 207., 215. 
vallomást, külsérelmi nyomok nélküli, rettenetes fájdalmat fog neki okozni egy szakértő, aki már útban is van helikopterrel. A fenyegetés hatására az örizetes megtört, és vallomást tett. A vallomásában megjelölt helyen a rendőrség megtalálta a sértett holttestét, a kisfiút az elkövető már az őrizetbe vétel előtt megfojtotta. A túszejtő életfogytig tartó szabadságvesztést, míg Daschner tízezer-nyolcszáz euró pénzbüntetést kapott - öt évre felfüggesztve. S bár az utóbbi ítélete Németországban is rendkívül enyhének számított, az ítélet indokolásában a bíróság kiemelte, hogy a kínzás abszolút tilalma alól semmilyen körülmények között nem tehetök kivételek; akkor sem, ha Daschner motívuma minden kétséget kizáróan méltányolható okból származott. ${ }^{19}$

Az alkotmányos büntetőeljárás axiómája, miszerint a jogtalanság ellen csak a jogállam eszközeivel lehet harcolni - gondolatiságában nem új keletü. Már Angyal Pál is kifejtette álláspontját a kérdésben: „, A büntetőeljárás során érvényesülni törekvő igazságszolgáltatási érdek állandó ellentétben áll az egyéni jogok érintetlenségének érdekével, mert az eljárás sikeres lefolytatása nem történhet meg anélkül, hogy az egyszerüen csak gyanúsitott egyénnek, söt az eljáráson kívül esö személyeknek legszemélyesebb jogai (személyes szabadság, házjog, levéltitok joga, stb.) ne korlátoztassanak. Valósággal alkotmányjogi szempontok állnak itt szemben a processzuális követelményekkel, s ezek akármelyikének kizárólagos érvényre emelése vagy túlsúlyra juttatása rendkívüli veszélyekkel járna.” Mint Balogh helyesen mutat reá: az egyéni jogok figyelmen kívül hagyása ezekre végzetes lenne, mert ha már egyszerü gyanú alapján bárkinek legszemélyesebb jogai minden korlát nélkül csorbíthatók, úgy közel fekszik annak lehetősége, hogy e jogok nemcsak a gyanúsítottnál, hanem egészen ártatlan egyéneknél is áldozatul essenek. Viszont az is tagadhatatlan, hogy az alkotmányjogi szempontok túlsúlyra juttatása az eljárás sikerét teszi kockára, mi annál veszedelmesebb, mert a jelen idők ratifikált büntettesei ily körülmények között könnyüszerrel szabadulnának az igazságszolgáltatás sújtó keze alól. ${ }^{20}$ Hasonlóan érvel Hacker Ervin is. aki szerint a büntető igazságszolgáltatás érdekei sokszor ellentétbe kerülnek az egyéni jogok érinthetetlenségeinek szempontjaival. Alkotmányjogi okok teszik szükségessé, hogy az egyéni jogok biztosításának elve érvényesüljön. ${ }^{21}$

\footnotetext{
19 www.spiegel.de 20. 12. 2004. Az eset szakirodalmi feldolgozását lásd Florian Jessberger: Bad Torture - Good Torture? Journal of International Criminal Justice, vol. 3, iss. 5. http://www.oxfordjournals.org/our_journals/jicjus/bad\%20torture.pdf

20 Angyal Pál: Az egyéni jogok biztosításának elve. A magyar büntetőeljárás tankönyve. I. kötet. Budapest, 1914, 271-274. o. In: Tóth Mihály (szerk.): Büntető eljárásjogi olvasókönyv. Osiris Kiadó, Budapest, 2003, 43. o.

21 Hacker Ervin: Alapelvek. In: Tóth Mihály (szerk.): i. m. 47. o.
} 
Az alkotmányjog tehát elsősorban az emberi és állampolgári alapjogok szabályozása terén teremt kapcsolódási pontokat a büntetőeljárás-joggal; Farkas Ákos szerint az alkotmányjog sok esetben alkalmazott büntetőeljárásjognak tekinthetô. ${ }^{22}$ Egyetértve Farkas Ákossal ez csupán azzal egészítendő ki, hogy a tézis fordítva is igaz: nevezetesen a büntetőeljárás sok esetben alkalmazott alkotmányjog. Székely György szerint: „A büntetőeljárás egész menete alkotmányos kérdés, mert lényegéböl eredöen az egyén alkotmányos jogait érinti. ${ }^{23}$ A Farkas Ákos-Pap Gábor szerzőpáros is arra a következtetésre jut, hogy „,az állami büntető igény érvényesitése nem járhat az egyén alkotmányos jogainak sérelmével, hiszen ha nem igy történik, akkor a megsértett jogrend védelmére hivatott állam az egyén jogainak sérelmén keresztül a jogrendet sérti meg" "24. Az alkalmi sikerekért nem szabad feláldozni a büntető igazságszolgáltatás időtálló értékeit; nincs mindenáron való igazságszolgáltatás, de nincs alanyi jog az igazság megállapítására sem. A bünüldözés kudarcait az állam viseli, azok nem háríthatók a gyanúsítottakra, nincs olyan magasabb érdek, amely alapján az ártatlanság vélelme korlátozható lenne. ${ }^{25}$

Az anyagi igazságosság érvényesülésének jogállami követelménye csak a jogbiztonságot szolgáló - elsősorban eljárási - garanciák, jogintézmények keretein belül maradva valósulhat meg. ${ }^{26} \mathrm{~A}$ jogállam értékrendjének meghatározó pillére a jogállami garanciák tényleges érvényre jutása a jogintézmények müködése/müködtetése során. Ellenkező esetben sérül a jogbiztonság, a jogszabályok következményeinek kiszámíthatósága, és esetlegessé válik az alapvető alkotmányos jogok érvényre jutása. A jogállami garanciák mellőzésére ezért sem célszerüségi, sem igazságossági szempontok nem adnak alapot. ${ }^{27} \mathrm{~A}$ jogállamiság, valamint az alkotmányos büntetőjog követelményei megkívánják, hogy az állam a büntetőhatalmát olyan szabályok szerint gyakorolja, amelyek egyensúlyt teremtenek az egyéneket az állammal szemben védő garanciális rendelkezések, ezen belül elsősorban a büntetőeljárás alá vont személy alkotmányos jogainak védelme és a büntető igazságszolgáltatás megfelelő müködésével kapcsolatos társadalmi elvárások között. ${ }^{28} \mathrm{~A}$ jogalkotónak ezen alkotmányos kereteken belül kell

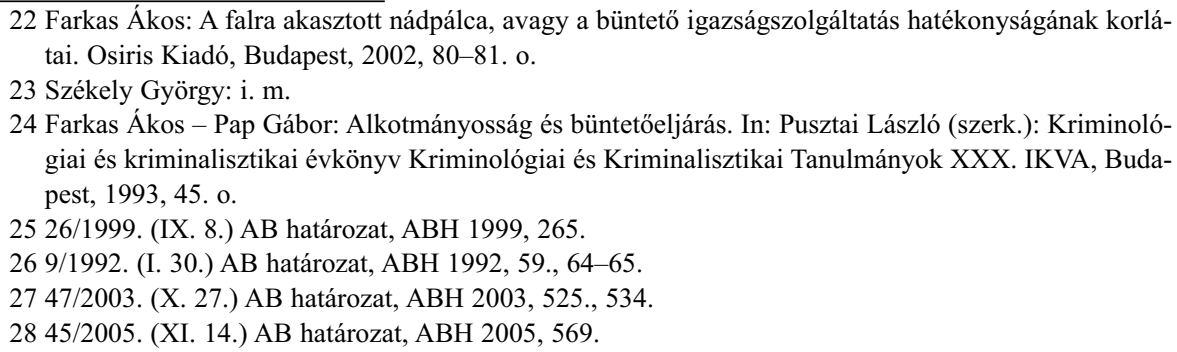


megtalálnia azokat az eljárási megoldásokat, amelyek a bünüldözés sikertelensége állami kockázatának csökkentését szolgálják. ${ }^{29}$

A demokratikus értékek feladása még súlyos bünözési helyzetben sem elfogadott, a bünözés és a nemzetközi bünözés elleni küzdelem csak az emberi jogok tiszteletben tartásával és a jog uralmából fakadó követelmények szerint valósulhat meg. ${ }^{30} \mathrm{Az}$ alkotmányos értékek védelme a rendészet olyan alapfeladata, amelynek megvalósításától semmilyen körülmények között nem tekinthet el.

Ha a bünüldözés és a rendvédelem hatékonyságának erősítése érdekében a rendőrség számára megnyitjuk a lehetőséget az emberi jogok megsértésére, a helyzet további problémákkal terhelődik. A törvény kikényszerítőjéből a törvény ellenszegülője válik. A civil társadalom elveszíti a közrend és a közbiztonság védelmezőjébe vetett hitét, a rendőrség izolálódik a közösségtől, amelynek értékeit védeni hivatott. A bünös szabadon távozik a hatóság épületéből, míg az ártatlan bármikor eljárás alanyává válhat. A sértett igazságszolgáltatás nélkül marad, sérelmei nem nyernek orvoslást. A rendőrség reaktívvá válik, nem törekszik már a büncselekmények megelőzésére, a társadalmi érdektelenséget tolmácsolja csupán. ${ }^{31}$

Ha azonban a rendőrség szem elött tartja az emberi jogok tiszteletét, az hosszú távon kifizetödik a bünüldözés és a rendvédelem hatékonysága tekintetében is. A rendőrök (jogilag is) magasan képzett szakmai állománya a problémamegoldásban és a büncselekmények megelözésében eredményes, és ezáltal a közrend védelme is sikeres lesz. A rendőrség és a közösség kapcsolata a bizalmon alapul, a bírói igazságszolgáltatás jogcentrikus. A rendőrség valódi szociális funkciót lát el már önmagában a példaértékü intézkedések felmutatásával. A rendőri intézkedések a legalitás elvén, a szükségesség és arányosság szem előtt tartásán, a diszkrimináció tilalmán és a humanitás védelmén alapulnak. Mivel a rendvédelmi szervek közvetlen kapcsolatban vannak a közösséggel, a megelőzésre fókuszáló és proaktív büntetőpolitika a leginkább hatékony ebben a rendszerben. ${ }^{32}$

A rendvédelmi szervek feladata a jogszabályban meghatározott eljárási keretek között szolgálni a közösséget és megvédeni annak tagjait a jogellenes cse-

\footnotetext{
29 14/2004. (V. 7.) AB határozat, ABH 2004, 241., 255.

30 Tóth Judit: A rendészet alkotmányossági minimumai és az alaptörvény. Közjogi Szemle, 2011/2., 23. o.

31 Human Rights and Law Enforcement. Office of the United Nations High Commissioner for Human Rights. New York-Geneva, 2002, p. 16.

www.ohchr.org/Documents/Publications/training5Add2en.pdf 32 Uo.
} 
lekményektől. Finszter Géza a rendészeti igazgatás alkotmányos fundamentumainak kialakítására három modellt állít. ${ }^{33}$ Első megoldásként az alkotmányok meghatározott köre részletesen szabályozza vagy legalábbis meghatározza a rendészeti szerveket és azok müködését (ez a rendészet pozitív meghatározása az alkotmányban). Második helyen Finszter azt a megközelítést említi, amikor az alkotmány a közigazgatás törvényes müködésének kereteit írja le anélkül, hogy abban külön kiemelné a rendőrséget és más rendészeti hatóságokat (a rendészeti igazgatás áttételes szabályozása). A harmadik technika az alapjogok katalógusa, amely negatív szabályként azt fogalmazza meg, hogy mit nem tehetnek meg a hatóságok még akkor sem, ha a tilalmazott eljárásokkal egyébként - legalábbis rövid távon - a közbiztonság hatékonyabb oltalmazása elérhető lenne (a rendészet negatív alkotmányos szabályozása). A különböző megoldások alkalmazására egyes alaptörvényekben együttesen kerül sor, míg más alkotmányok azok egyikét vagy másikát követik.

Tóth Judit szerint lényeges az alaptörvény azon változtatása, hogy csak közvetett módon szabályozza a rendészetet és annak alkotmányos követelményét. ${ }^{34}$ Valójában azonban nem az a fontos, hogy a rendvédelmi szervek jelentős helyet kapjanak az alkotmányban/alaptörvényben, hanem az, hogy az emberi jogok, alkotmányos alapjogok jelentős szerepet játsszanak a rendvédelem müködésében. Az alkotmányos demokrácia értékeinek érvényre juttatása az állami szervek müködésében, a jog uralma, a hatalmi ágak megosztásának elve, és az emberi jogok védelme a rendészet alapértékei. A rendészet által is védett alkotmányos értékek meghatározása (például közrend, közbiztonság, köznyugalom, közerkölcs, véleménynyilvánítás szabadsága, tisztességes eljárás, jogorvoslati jog) az Alkotmánybíróság vonatkozó határozataiban is tükröződik.

További lényeges kérdés, hogy alkotmányos berendezkedésekben a honvédelem és a rendvédelem élesen elválik egymástól, mert csak ilyen módon érvényesíthetők a demokratikus rendszerek müködési alapelvei, amelyek között első helyen az emberi jogok tisztelete áll. Magyarországon 1949 óta centralizált, katonai elvekre épülő, a civil közigazgatástól elkülönülő államigazgatási rendőrségi modell müködik, amelyen sem az 1989-es köztársasági alkotmánymódosítás, se a határőrség kettős jogállásának (egyszerre fegyveres erő és rendészeti szerv voltának) 2004. évi megszünése, sem a rendőrségbe történt

\footnotetext{
33 Finszter Géza: Bevezetés a rendészettudományokba. Jegyzet. Rendőrtiszti Főiskola, Budapest, 2008, 51-52. o.

34 Tóth Judit: i. m. 26. o.
} 
2008. évi integrációja nem változtatott. ${ }^{35}$ A rendészeti szervek rendvédelmi arculatot csak a különleges jogrend bevezetése után vesznek fel. Mind a normál, mind a különleges jogrend bevezetését követő eljárásokban alapvető elvárás azonban, hogy a törvény elött mindenki egyenlö; eljárásuk során a rendőri szervek sem tehetnek különbséget fajra, nemre, vallásra, nyelvre, bőrszínre, politikai véleményre, származásra, tulajdonra, születésre vagy egyéb státusra tekintettel. Különleges bánásmódot igényelnek azonban a nők (különösen a terhesek és az újszülöttet nevelők), a fiatalkorúak, az idősek, és a testi, szellemi vagy egészségi állapotuk miatt hátrányos helyzetủek.

A büntetőeljárás és a rendészeti feladatok ellátása során számtalan esetben felvetődik valamilyen alapjogi probléma, vagy alapjogok összeütközése. ${ }^{36} \mathrm{~A}$ nyomozás során például, különösen a terhelti és tanúkihallgatásoknál, továbbá a motozásnál, (ház)kutatásnál, lefoglalásnál stb. tiszteletben kell tartani a magánélet védelmét. Az ártatlanság vélelmének szem előtt tartásával kifejezetten tilalmazott az önkényes beavatkozás az eljárás alá vont személy magán- és családi életébe. A vallomás kikényszerítése céljából tilos a kínzás, embertelen és megalázó bánásmód alkalmazása, testi vagy lelki nyomásgyakorlás. A sértettekkel és a tanúkkal a hatóság tagjainak emberségesen kell bánniuk, az eljárásban megszerzett információkat az ö vonatkozásukban is bizalmasan kell kezelni. Az önvádra kötelezés tilalma és a tisztességes eljáráshoz való jog mindvégig érvényesül a nyomozás során. A nyomozás lefolytatása nem lehet jogellenes, önkényesen meghatározott, annak szakszerünek, kompetensnek kell lennie, az eljáró hatóság tagjainak pedig pártatlanoknak. A személyi szabadságától bárkit megfosztani csak az eljárási törvény rendelkezéseinek megfelelő feltételrendszer és végrehajtási szabályok alapján lehet; az érintettet tájékoztatni kell az őrizetbe vétel okáról. Az őrizetbe vett vagy letartóztatott személy részére biztosítani kell, hogy védővel konzultálhasson. Ha szükséges, a kihallgatott részére tolmácsot kell biztosítani.

A személyi szabadságtól történő megfosztás alapjául szolgáló eljárás törvényben meghatározott kell hogy legyen. A törvényi feltételrendszer meghatározása kiterjed arra, hogy minek érdekében történik az alapjog-korlátozás; mely szerv elé történik az előállítás; mennyi időtartamot foghat át az elvonás; és milyen kötelezettségek terhelik a végrehajtás során a hatóságot. A letartóztatás csupán kivételesen foganatosítható, alkalmazása nem lehet általános. A személyi szabadságától megfosztott terheltet is ártatlannak kell tekinteni

\footnotetext{
35 Finszter Géza (2018): i. m.

36 Kiss Barnabás: Emberi jogok - alapjogok általános kérdései. Tansegédlet. 6. o., 3. pont. http://www.juris.u-szeged.hu/download.php?docID=48277
} 
mindaddig, amíg bűnösségét a bíróság - tisztességes eljárás keretében - jogerősen meg nem állapítja. A letartóztatott személyt nem lehet kínzásnak alávetni; kegyetlen, embertelen vagy megalázó bánásmódban részesíteni, vagy ezek alkalmazásával fenyegetni. A letartóztatás csak a hivatalosan erre kijelölt helyen hajtható végre; a letartóztatott családja és védője tájékoztatásra jogosult a végrehajtás helyéről, és kapcsolatot tarthat a letartóztatottal. A fiatalkorúakat a felnőttkorúaktól, a férfiakat a nőktől, a jogerősen elítélteket a letartóztatottaktól el kell különíteni.

A testi erőszak alkalmazása és a fegyverhasználat során kiemelt fontosságú az élethez és az emberi méltósághoz való elidegeníthetetlen emberi jog. Ennek megfelelően mind az erőszak, mind a fegyverhasználat csak végső eszközként funkcionálhat, a szükségesség szempontrendszerének alapos vizsgálata után. Fegyverhasználat csak kivételes körülmények esetén lehetséges: például önvédelemből vagy más személy életének, testi épségének védelme érdekében; kiemelkedően súlyos büncselekmény megakadályozása céljából; menekülő elkövető elfogása végett. A végrehajtás előtt a rendőrnek azonosítania kell magát ebbéli minőségében, és egyértelmü utasítást és figyelmeztetést kell adnia az intézkedéssel érintett személynek. A végrehajtás során az okozott sérülés minimalizálására kell törekedni. A fegyverhasználatról jegyzőkönyvet kell készíteni, amelyet az elöljáró véleményez.

\section{Konkrét alapjogok, konkrét határozatok}

A rendészet alkotmányossági vizsgálata során elsődleges az érintett alapjogok körvonalazása. A rendvédelmi hatóságok beavatkozása leggyakrabban a személyi szabadságot, az emberi méltóságot, illetve a magánélet védelmét sérti. A jogállamiság alapvető értékeit meghatározó elveket az Alkotmánybíróság az egyedi esetek fényében értelmezi. ${ }^{37} \mathrm{~A}$ tanulmány a továbbiakban az egyes alapjogok korlátozhatóságának viszonyrendszerét az Alkotmánybíróság vonatkozó határozatainak fényében vizsgálja.

Az élethez való jog kapcsán - egyebek között - a löfegyverhasználat alkotmányosságának vizsgálatát végezte el az Alkotmánybíróság. A testület szerint a használat alkotmányosságát fő szabály szerint az alapozza meg, hogy az érintett személy korábban megsértette az élethez való jogot egy másik ember életének kioltásával. Aki más életének kioltásával megsérti az élet-

37 9/1992. (I. 30.) AB határozat, ABH 1992, 59., 64-65. 
hez való jogot, nem kerül és nem is helyezhető a jog világán kívül, de magára vonja azt a kockázatot, hogy - a törvényben meghatározott feltételek beállása esetén - a vele szemben alkalmazható jogszerü lőfegyverhasználat révén a saját élete kerül veszélybe. Ennek a helyezetnek a kialakulásához szándékos magatartások összefüggő zárt láncolata az előfeltétel, amelyet a törvény meghatároz. Az első szándékos magatartás az emberölés. A második, hogy az érintett nem szándékozik alávetni magát a jogi eljárásnak: nem jelentkezik önként a hatóságnál, nem engedi elfogni magát. A harmadik, hogy a konkrét rendőri intézkedésnek nem engedelmeskedik, menekül. A negyedik, hogy sem a figyelmeztetés, miszerint lőfegyverhasználat következik, sem a figyelmeztető lövés leadása nem változtatja meg abbéli szándékát, hogy kivonja magát a büntetőeljárás alól. Az érintett tehát döntési helyzetben van, mert rendelkezésére áll annyi idő, ami elegendő arra, hogy ő maga akadályozza meg az életét kockáztató helyzet kialakulását. Az Rtv. 56. § (2) bekezdése alapján a megelőző intézkedések részben vagy egészben mellőzhetők ugyan, de csak akkor, ha egyébként a rendőr vagy más személy élete kerülne veszélybe. Utóbbi helyzet alkotmányossági megítélése viszont már egy másik löfegyverhasználati körbe tartozik, amelyet a konkrét életveszélyeztetés alapoz meg [Rtv. 54. §a), b), vagy k) pont].

A rendvédelmi szervek beavatkozása tehát különböző alapjogokat érinthet. Az egyes alapjogok pedig további összetevőkre bonthatók, az emberi méltósághoz való jog fontos része például az önrendelkezéshez való jog, a magánszféra védelme, és ennek egyik speciális aspektusa, az adatvédelem. A mindenkit megillető, a személyisége szabad kibontakozásához, az önrendelkezéshez és a személyes adatok védelméhez füződő jogból az Alkotmánybíróság levezette továbbá azt is, hogy a büncselekmények elkövetéséhez füzödő következmények hatóköre sem lehet korlátlan. Az elítélés ténye a büntetőjogon kívüli szférában nem vezethet szükségtelen korlátozásokhoz; a szabályozás során figyelembe kell venni a személyes adatokhoz való jogot és az emberi méltóságoz való alapjogot.$^{38} \mathrm{Az}$ információs önrendelkezéshez való jog szoros kapcsolatban áll az emberi méltóságoz, a személyiség szabad kibontakozásához való joggal. Ebből az is következik, hogy az adatalanyt megilleti az a garancia, hogy adatait azok valóságtartamának megfelelően csak a legszükségesebb időtartamban és adatmennyiségben, az adatbiztonság szabályainak megfelelően kezeljék. A büntetett előélethez füződő hátrányok alól már mentesült személyek esetében nincs a további adatkezelésnek olyan ál-

38 144/2008. (XI. 26.) AB határozat, ABH 2008, 1107. 
talános célja, amely meggyőzően indokolná, hogy ezek az adatalanyok miért a büntetőeljárás vagy a hátrányos jogkövetkezmények hatálya alatt állókkal esnek azonos megítélés alá, nem pedig más büntetlen előéletủ természetes személyekkel. Az egyenlő méltóságú személyekként történő kezelés szempontjából a büntetlenség ,állapota" szolgálhat az adatalanyok helyzetének összehasonlításául. ${ }^{39}$ A személyes adatok nyilvánosságra hozása vonatkozásában az Alkotmánybíróság akként foglalt állást, hogy ,, a közrend, köznyugalom megteremtése, biztositása megköveteli az elkövetök megbüntetését és azt is, hogy a nyilvánosság tájékoztatást kapjon különösen a köznyugalmat megzavaró vagy más súlyos büncselekmények körülményeiröl és a felderités érdekében tett intézkedésekröl, az eljárás állásáról, valamint arról is, hogy a büncselekményeket kik követték el. A közbiztonság, a köznyugalom védelme, mint alkotmányosan elismert államcél megteremtése indokolttá teszi tehát a büncselekményt elkövetök bizonyos adatainak nyilvánosságra hozatalát." ${ }_{40}$ Ugyanakkor a törvénnyel történő alapjog-korlátozással összefüggésben az Alkotmánybíróság kiemelte, majd a 46/1995. (VI. 9.) AB határozattal még markánsabb követelménnyé tette, hogy a szükségességet szigorú mércével kell mérni. Erre nem kerülhet sor túl általánosan meghatározott okok, például szervezetek „feladatainak ellátása”, „mások érdekeinek védelme”, ,jogos érdekek" és más hasonló megragadhatatlan kategóriák, vagy önmagában közérdekre hivatkozás alapján. ${ }^{41} \mathrm{Az}$ elkerülhetetlenség és szükségesség a „közérdeknél" szigorúbb alkotmányos követelmény, vagyis az Alkotmánybíróság a „közérdek” fennállásának és alkotmányos indokának vizsgálatánál is a „szükségesség-arányosság” ismérveit alkalmazza. ${ }^{42}$ A különleges személyes adatok kezelésével összefüggésben a 65/2002. (XII. 3.) AB határozat külön kiemelte, hogy az alapjog-korlátozásra az adatminőségre tekintettel szigorú követelmények vonatkoznak. Az adatkezelési müveletek, az elvégzésükre való feljogosítás, a célhoz kötöttség szabályainak az adatigénylő oldalán való megléte, az adatfeldolgozók pontos körének és az igényelhető adatkörnek a meghatározása közvetlen kapcsolatban áll az alapjog lényegével, és speciális garanciákat igényel. ${ }^{43}$

\footnotetext{
39 44/2004. (XI. 23.) AB határozat, ABH 2004, 618. $40 \mathrm{Uo}$.

41 Uo.

42 15/1991. (IV. 13.) AB határozat, ABH 1991, 40., 45., 47.; 46/1995. (VI. 30.) AB határozat, ABH 1995, $219 ., 224$.

43 65/2002. (XII. 3.) AB határozat, ABH 2002, 357., 363., 364.
} 
A titkos információgyüjtés az egyik legsúlyosabb alapjog-korlátozó intézkedés. Alkalmazását az a körülmény alapozza meg, hogy a társadalom rendjét súlyosan sértő vagy veszélyeztető büncselekmények elleni eredményes fellépéshez sokszor a büntetőjog hagyományos eszközei már nem elegendők. Olyan eszközökre és módszerekre van szükség, amelyek behozhatják a bünüldöző szerveknek a bűnözéssel szemben fennálló lépéshátrányát. Ezáltal az érintett alapjogok korlátozása alkotmányosan nem szükségtelen. Bünüldözési célból történő igénybevételükre csak kivételesen, ultima ratióként, differenciált szabályozás mellett és csak akkor kerülhet sor, ha a nyílt eljárásban rendelkezésre álló eszközök felhasználásával a büncselekmény felderítése, az elkövető és a bizonyítékok felderítése kilátástalan. ${ }^{44} \mathrm{~A}$ titkos adatgyüjtés tehát jellegéből fakadóan csakis ultima ratióként, vagyis végső eszközként ideiglenes jelleggel alkalmazható.

A titkosszolgálati eszközök alkalmazása során fellépő alapjogi korlátozás kapcsán az Alkotmánybíróság leszögezte, hogy „A titkos eszközök és módszerek alkalmazása alapvetöen korlátozza a magánélet, családi élet, magánlakás és levelezés tiszteletben tartásához, valamint ehhez szorosan kapcsolódva az információs önrendelkezéshez, az információáramlás szabadságához és a személyes adatok védelméhez való jogot" ${ }^{\text {"45 }}$. Vagy ahogyan egy másik határozatában fogalmaz az Alkotmánybíróság: „, A titkos eszközök és módszerek alkalmazása szükségképpen a magánszféra legszorosabban vett tartományát, az egyéni autonómia kiteljesedésének terepet adó magánlakást, az ott folyó individuális tevékenységet és a magánlakás védelmével szorosan összefüggö, de az emberi méltóságoz való jogtól szintén el nem választható magántitkokat korlátozzák. " ${ }^{46}$ A magánszférához való jog és a magánélet szabadságához való jog az egyén autonómiájának védelmére szolgáló olyan alapjog, amely az ember veleszületett, elidegeníthetetlen méltóságából ered. ${ }^{47} \mathrm{~A}$ titkosszolgálati eszközök alkalmazására sor kerülhet nemzetbiztonsági, bünfelderítési ezen belül is rendészeti és bünüldözési és igazságszolgáltatási célból. A nemzetbiztonsági célú titkosszolgálati eszközök kapcsán az Alkotmánybíróság leszögezte: „A nemzetbiztonsági érdekek védelme alkotmányos cél és állami kötelezettség. Az ország szuveneritása és alkotmányos rendje a demokratikus jogállam müködéséhez nélkülözhetetlen alapértékek. Az ország szuveneritásának érvényre juttatása, politikai, gazdasági és honvédelmi érdekeinek

44 2/2007 (I. 24.) AB határozat, ABH 2007, 65

$45 \mathrm{Uo.}$

46 Uo.

47 56/1994. (XI. 10.) AB határozat, ABH 1994, 312. 
megóvása, a szuveneritást, illetöleg az alkotmányos rendet sértő vagy veszélyeztetö tevékenységek felderitése és elháritása az államnak az Alkotmányból közvetlenül levezethetö kötelezettsége." "48 Figyelemre méltó a testület álláspontja a bünüldözési célú titkos információgyüjtés jogi szabályozásáról is. ${ }^{49}$ E szerint az alapjogokba történő titkos beavatkozás a végrehajtó hatalomnak „beláthatatlan” lehetőségeket ad, így elengedhetetlen, hogy már maguk az eljárások kellő garanciát nyújtsanak az egyén jogainak érvényesülésére. A szükségesség és arányosság követelménye tehát nemcsak a jogalkalmazásra, hanem a jogalkotásra is érvényes kritérium. Az arányosság védelme érdekében az Emberi Jogok Európai Bíróságának ítéleteit ${ }^{50}$ figyelembe véve az Alkotmánybíróság is megfogalmazza, hogy elsősorban állandó, folyamatos, a végrehajtó hatalomtól független szerv által végzett kötelező ellenőrzés nyújthat megfelelö garanciát arra, hogy adott ügyben ne sérüljön az arányosság követelménye.

Az Emberi Jogok Európai Bírósága a világos normatartalom körében arra is rámutatott, hogy a törvényeknek tartalmazniuk kell a beavatkozást indokoló eseteket, körülményeket és a beavatkozás feltételeit. Minimális biztosítékként szerepelnie kell bennük továbbá az érintett személyek körének meghatározására alkalmas feltételeknek, az alkalmazás dokumentálására és a dokumentáció megóvására, valamint megsemmisítésének szabályaira vonatkozó rendelkezéseknek. Az alkalmazásról szóló döntés meghozatala körében pedig a hatóságok nem kaphatnak túl széles mérlegelési jogot. ${ }^{51} \mathrm{Az}$ alkalmazás garanciáihoz tartozik továbbá az is, hogy külső személyek számára az információkhoz való hozzáférést korlátozni kell. ${ }^{52} \mathrm{Az}$ alkalmazás szükségességének megítélésénél alapvető, hogy az alkalmazásra csak ,minősített” (súlyos) fenyegetés esetén van mód, s csak akkor, ha a hagyományos nyomozási eszközök az ügy körülményei miatt hatástalannak bizonyulnak, és arra csak elözetesen megismerhető szigorú eljárási rendben kerülhet sor. ${ }^{53}$

A titkos információgyüjtés kontrolljára vonatkozó két lényeges követelmény, hogy egyrészt a titkos eszközök alkalmazását lehetővé tevő eljárási rendnek kellő garanciát kell nyújtania az egyén jogainak védelmére, másrészt a garanciát nyújtó kontrollnak a végrehajtó hatalomtól függetlennek kell len-

\footnotetext{
48 13/2001. (V. 14.) AB határozat, ABH 2001, 177.

49 2/2007. (I. 24.) AB határozat, ABH 2007, 65.

50 Például Valenzuela Contreras v. Spain.

51 Case of Valenzuela Contreras v. Spain, judgement of 30/06/1998., Reports 1998-V.

52 Case of Kopp v. Switzerland, judgement of 25/03/1998., Reports-1998-II.

53 Klass and Others v. Germany judgement of 6 September 1978, series A no. 28.; Halford v. United Kingdom judgement of 25 June 1997, Reports 1997-III.
} 
nie, az alapjogok hatékony védelme a bíróság feladata. ${ }^{54} \mathrm{Az}$ új büntetőeljárási törvény tervezete szerint leplezett eszközök az előkészítő eljárás és a nyomozás során alkalmazhatók. Előkészítő eljárás a bírói engedélyhez kötött leplezett eszközök alapjául szolgáló büncselekmények tekintetében folytatható a gyanú megállapítása céljából. A nyomozás során az ügyészség és a nyomozó hatóság jogosult leplezett eszközök használatára. Alapjogi szempontból az új törvényi szabályozás sarokköve lehet az elrendelés célhoz kötöttségének problematikája. Példával illusztrálva: ha a magánlakásban történtek titkos megfigyelését és rögzítését azért rendelték el, mert egy kábítószer-kereskedelemmel foglalkozó bünszervezet ellen történik az adatgyüjtés, de a lehallgatás során az eredeti ügyben egyébként nem érintett személy féltékenységből szándékos emberölést követ el, felhasználható-e az ilyen módon megszerzett bizonyítási eszköz, és megindítható-e a büntetőeljárás emberölés miatt. Az osztrák StPO erre lehetőséget ad [140. § (2) bekezdés], de nálunk a célhoz kötöttség elve esetenként sokkal megszorítóbb értelmezést kap. Ahogyan a példa is mutatja, a titkos eszközök alkalmazása rendkívüli hatalmat ad az alkalmazók - az állam büntetőhatalmát gyakorló szervek - számára, és különösen kiszolgáltatottá teszi az érintetteket. Ezért szabályozásuk és végrehajtásuk során szigorú, az alapjogokba való beavatkozás minden részletkörülményére kiterjedő garanciákra van szükség. ${ }^{55} \mathrm{~A}$ bírói engedélyhez kötöttség és a bírói kontroll megteremtése olyan garanciaként tud funkcionálni ezekben az esetekben, amely képes az állam intézményvédelmi kötelezettségének felmutatására.

A gyülekezési jogot ${ }^{56}$ érintő első jelentős AB-határozatban a testület arra a következtetésre jutott, hogy a gyülekezési jog nem korlátozhatatlan jog; ahogyan a többi alkotmányos alapjog, a gyülekezési jog is korlátozható, meghatározott törvényi keretek között. ${ }^{57} \mathrm{Az} \mathrm{AB}$ azonban rámutatott, hogy a gyülekezési jog értelemszerủen az egyént megillető emberi jog, amelynek gyakorlása viszont fogalmilag csak csoportosan történhet. A határozat kapcsán kiemelendő Kukorelli István alkotmánybíró különvéleménye, aki hangsúlyozta, hogy az önhatalmú hatósági fellépés elleni alkotmányos védelemhez nem elég a jogalkalmazóba vetett bizalom, hanem ahhoz jogszabályi és szervezeti garan-

\footnotetext{
54 Finszter Géza: Bünüldözés és jogállam. Ügyészségi Szemle, 2016/1., 30. o.

55 2/2007. (I. 24.) AB határozat, ABH 2007, 65.

56 Merkl Zoltán a gyülekezési jog tartalmi elemeinek kifejtésére, illetve a jogi szabályozás pontatlanságaira hívja fel a figyelmet. Merkl Zoltán: A gyülekezési jog hatása a rendőri intézkedésekre, a változások indokai. Belügyi Szemle, 2015/5., 61-63. o.

57 55/2001. (XI. 29.) AB határozat, ABH 2001, 442.
} 
ciák szükségesek. ${ }^{58} \mathrm{Az}$ első gyülekezési határozat valójában nem a gyülekezési jog alkotmányos tartalmát értelmezte, hanem a gyülekezési törvény és az alkotmány összhangját vizsgálta. ${ }^{59}$ A második, flash mob néven elhíresült és a gyülekezési jogról szóló AB-határozat megállapította, hogy az alkotmány 62. §-ában található és a békés gyülekezéshez való jogról szóló szabályozás kiterjed azokra az előzetesen szervezett rendezvényekre (közöttük a békés rendezvények megtartására), amelyekre a gyülekezésre okot adó esemény miatt csak rövid időn belül kerülhet sor. A gyülekezési jog kiterjed továbbá az előzetes szervezés nélküli gyülésekre is. Az előzetes bejelentési kötelezettség a közterületen tartandó, szervezett rendezvényekre vonatkozik. Önmagában a késedelmes bejelentkezésre hivatkozással azonban nem tiltható meg azoknak a békés rendezvényeknek a megtartása, amelyek a gyülekezésre okot adó esemény miatt nem jelenthetők be három nappal a rendezvény időpontja előtt. ${ }^{60}$ Badó Katalin szerint az első gyülekezési határozat elvi alapjaitól nem történt elmozdulás a flash mobra vonatkozó határozatban: így például megerősítést nyert, hogy a gyülekezési törvény keretszabályozást tartalmaz, a konkrét ügyekben való alkalmazás minden esetben a rendőrségi, illetve a bírósági jogalkalmazókra tartozik. A határozat foglalkozott a mozgás- és helyváltoztatás és a gyülekezési jog összefüggéseivel, valamint ennek időbeli kihatásával is. Külön vizsgálta a bejelentési kötelezettség, illetve az annak elmaradása esetén beálló jogkövetkezményeket, és ezek esetleges alapjogkorlátozó hatását. A visszaélésszerü joggyakorlást illetően azt nemcsak a hatóságok, hanem a gyülések szervezői, rendezői, résztvevői részéről is fennálló veszélyként értékelte azzal, hogy a mindenkit megillető gyülekezési jog nem csorbítható azon az alapon, hogy néhányan esetleg visszaélnek vele. Végül az állam alapjogvédelmi kötelességére rámutatva kimondta, hogy e kötelesség nem merül ki egy-egy törvény elfogadásával, hanem folyamatos hatásvizsgálatot igényel. ${ }^{61}$

A rendészet és az alapjogok kapcsolata nem csupán a rendvédelmi szervek és az állampolgárok viszonylatában érvényesül, hanem a rendvédelmi hatóság tagjainak az alapjogaira is figyelemmel kell lenni. Ez a szempontrendszer sokszor háttérbe szorul, és a figyelem kizárólag az állampolgárokkal szemben elkövetett jogsértésekre irányul. Az alapjogok és a rendészet kapcsolata azon-

\footnotetext{
58 55/2001. (XI. 29.) AB határozat, ABH 2001, 467-477. Kukorelli István különvéleménye.

59 Badó Katalin: A gyülekezési jog értelmezése az Alkotmánybíróság döntéseinek tükrében. Rendészet és emberi jogok, 2011/2., 7. o.

60 75/2008. (V. 29.) AB határozat, ABH 2008, 651.

61 Badó Katalin: i.m. 13. o.
} 
ban több dimenzióban értelmezendő, erre példaként szolgálhatnak a rendőr képmásának nyilvánossága kapcsán keletkezett alkotmánybírósági határozatok $^{62}$, és a Kúria jogegységi döntései ${ }^{63}$, illetve elvi határozata ${ }^{64} \mathrm{~A}$ rendvédelmi dolgozók képmása viszonylag széles körben lehet nyilvános a beleegyezésük nélkül is, azonban a konkrét eset kapcsán vizsgálandó kritériumok értelmezése kapcsán nem szerencsés eset állt elő, amikor az Alkotmánybíróság több határozatában is ellentmondott a Kúria állásfoglalásának. ${ }^{65}$

\section{Összegzés}

A tanulmány a jogállamiság és a rendészet kapcsolatát elemezve arra a megállapításra jut, hogy a ,jogállam” kifejezés éppen a rendészettel összefüggésben született meg; és bár manapság a ,jogállamiság” kifejezés használata során elsősorban már nem annak rendészeti aspektusára koncentrálunk, az alapjogok és a rendészet a mai napig szoros kapcsolatban vannak. És hogy mi a jogtudomány és a jogalkalmazás szerepe ebben a kérdésben? A jogtudomány figyelemmel kíséri és elemzi a rendészet és az alapjogok konfliktusait. Az így elért tudományos eredmények iránymutatásul, segítségül szolgálnak a rendvédelmi szervek számára abban, hogy feladatuk ellátása során megfeleljenek az alapjogi követelményeknek. A rendvédelmi szervek feladataik ellátása során ugyanis - ha nem is közvetlenül, de áttételesen - az alkotmányjogot (is) alkalmazzák.

Ami pedig az alkotmányos büntetőeljárást illeti: az alkotmányjogi szempontok gyakran szemben állnak a processzuális követelményekkel. Ezek bármelyikének kizárólagos érvényre juttatása azonban rendkívüli veszélyeket hordoz. Egyetértve Angyal Pállal: „A helyes megoldás ezeknél fogva csak a kompromisszum lehet, azaz az állami érdekeknek az egyének alkotmányos jogaival való összeegyeztetése olyan módon, hogy megállapittassék a bírói függetlenség, [...] hogy törvény szabja meg az eljárás kereteit az egyéni jogok korlátozásának feltételeit, hogy a terhelt, mint ügyfél, lehetöleg egy vonalra helyeztessék a vádlóval (ügyfélegyenlöség), de mindenesetre hogy a szabad védekezés biztosittassék (szabad védelem). ${ }_{66}$

\footnotetext{
62 28/2014. (IX. 29.) AB határozat, ABH 2014, 813.; 16/2016. (X. 20.) AB határozat, ABK 2016, 1204; 17/2016. (X. 20.) AB határozat, ABK 2016, 1212.

63 1/2012. BKMPJE; 1/2015. BKMPJE.

64 9/2016. számú polgári elvi határozat.

65 A szakmai vita részletes elemzését lásd Papp János Tamás: Az Alkotmánybíróság két újabb határozata a rendvédelmi dolgozók képmásának nyilvánosságáról. Jogesetek Magyarázata, 2016/6., 5-11. o. 66 Angyal Pál: i. m.
} 